\title{
The tapeworm Paradilepis scolecina (Rudolphi, 1819) (Cestoda: Cyclophyllidea) invasion in Great Cormorant [Phalacrocorax carbo sinensis (Blumenbach, 1798)] from the breeding colony in Lake Selment Wielki (northern Poland)
}

\author{
J. DZIEKOŃSKA-RYNKO ${ }^{1}$, E. DZIKA ${ }^{2}$
}

\begin{abstract}
${ }^{1}$ Faculty of Biology, Department of Zoology, University of Warmia and Mazury, Oczapowskiego St. 5, 10-957 Olsztyn, Poland, E-mail: jdr@uwm.edu.pl; ${ }^{2}$ Faculty of Medical Science, Department of Medical Biology, University of Warmia and Mazury, Żołnierska St. 14c, 10-561 Olsztyn, Poland
\end{abstract}

\begin{abstract}
Summary
The intensity and extensity of infestation of cormorants (Phalacocorax carbo sinensis) from a colony in Lake Selment Wielki with the tapeworm Paradilepis scolecina (Rudolphi, 1819) was examined. The cormorants were shot in April, August and October 2006 and in August and September 2007. The extensity of infection in all the cormorants under study was very high - even reaching $100 \%$. The highest intensity of infestation was found in the birds shot in August - 4697 tapeworms per bird in 2006 and 2562 in 2007 . The intensity of infestation in the birds which were shot in autumn was less than one-tenth of that found in the birds shot in summer. The lowest intensity of infestation was found in the spring of 2006 - 61 tapeworms per bird.
\end{abstract}

\section{Keywords: Paradilepis scolecina, Cestoda, Cormorant}

\section{Introduction}

The tapeworm Paradilepis scolecina (Rudolphi, 1819) is a cosmopolitan parasite of ichthyophagous birds (Rybicka, 1958; Korpaczewska, 1963; Scholz, 1989; Murai et al., 1996 - 97; Scholz et al., 2004). According to Jarecka (1970), the first intermediate host of the tapeworm in Poland is the crustacean Eudiaptomus graciloides (Copepoda), in whose body cavity a cercoscolex type larva develops 20 days after infection. The second intermediate hosts are fish, mainly Cyprinidae, in which the parasite develops to the stage of plerocercus. Cysts with plerocercuses were found in the body cavity, intestinal mesentery, liver and in the gallbladder wall of fish from various water reservoirs in Poland (Kozicka, 1971; Rolbiecki et al., 1999; Dzika, 2002, 2003; Rolbiecki, 2003). The intensity and extensity of infestation with this parasite is especially high in fish from the reservoirs situated close to cormorant colonies. The highest intensity (8.2 plerocercuses per fish on average) and extensity (65.8\%) of infestation with this tapeworm was found by Dzika (2003) in roach from Lake Wulpińskie, in which a cormorant colony is situated. The values were much lower for the roach caught in lakes situated farther away from cormorant colonies (Lakes Dgał Wielki, Warniak). The definitive hosts for P. scolecina are ichthyophagous birds, mainly the great cormorant (Phalacrocorax carbo) and the pygmy cormorant (Phalacrocorax pygmaeus), as well as the Dalmatian pelican (Pelecanus crispus) and the white pelican ( $P$. onocrotalus). Occasionally, ibises (Plegadis falcinellus) and falcated ducks (Anas falcata) become infected (Ryzhikov et al., 1985). The intensity of cormorant infestation the tapeworm can be very high. Rybicka (1958) found 900 tapeworms in one cormorant, while the 7 cormorants examined by Korpaczewska (1963) had from 58 to 2643 tapeworms. The extensity of infestation in both studies was found to be $100 \%$. Mass occurrence of the tapeworm in the jejunum of cormorants from the colonies situated in the Mazurian Lakes and the Vistula Lagoon was found by Szostakowska and Sulgostowska (2004). The main source of cormorant infestation by the parasites are cyprinids (Murai et al., 1996 - 97), which are a staple food for cormorants (Martyniak et al., 1997a, b, 2003).

The nature of pathogenicity of $P$. scolecina towards the indirect and definitive hosts has not been found. In the places infected by tapeworms in the fish's bodies extravasations and hypertrophy of the tissue surrounding the parasite may appear (Prost, 1994), and a large number of plerocercuses in the fish body cavity may facilitate the development of other diseases (Murai et al., 1996 - 97). The histopathological changes found by Dzika et al. (2005) in the liver and spleen of the roach may have been caused, in the author's opinion, by the presence of plerocercuses $P$. scolecina. In definitive hosts, a large number of tapeworms may cause extensive damage to the small intestine 


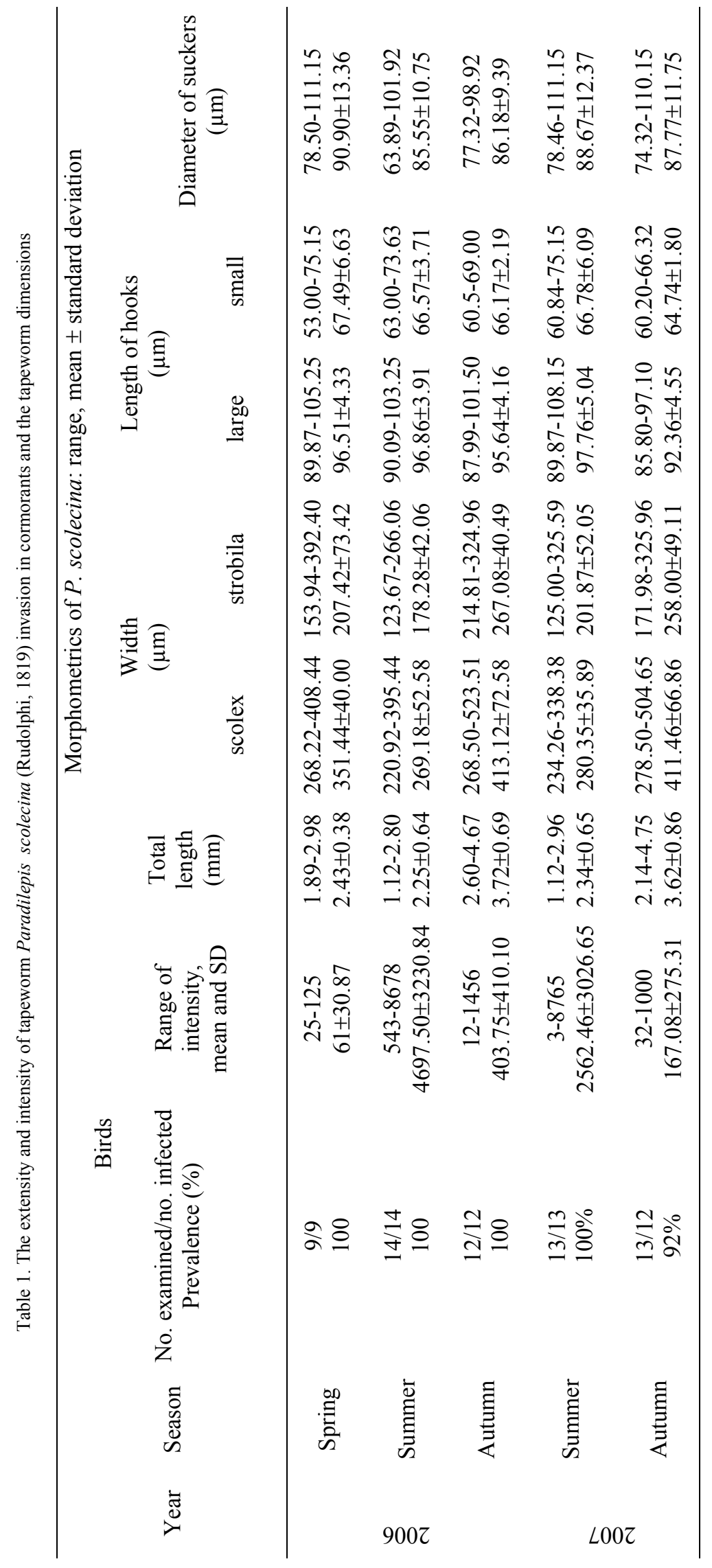


(Karstad et al., 1982). The damages observed by the authors were caused by tapeworm scolexes, penetrating deep into the intestine wall. Infiltrations of macrophage, eosinophil granulocytes and lymphocytes were found around the tapeworm cuticle.

The aim of this study was to examine the seasonal changes in the intensity and extensity of tapeworm $P$. scolecina infections in cormorants in the breeding colony on Lake Selment Wielki.

\section{Materials and methods}

The study was conducted in 2006 and 2007 in a colony situated on Lake Selment Wielki (the Province of Warmia and Mazury, the north-east of Poland). In 2006, cormorants were shot on 12 April (soon after the colony arrived), then on 27 August (when the young had grown) and on 4 October. In 2007 the first shooting was done on 24 August and the second on 28 September. A total of 61 birds were examined. Most of them were adult cormorants, only a few of them were young individuals. The birds' age was roughly estimated from the colour of plumage on their bellies. The entire alimentary tract was isolated for the study and divided into sections: oesophagus, stomach, small intestine, large intestine. Each section was cut

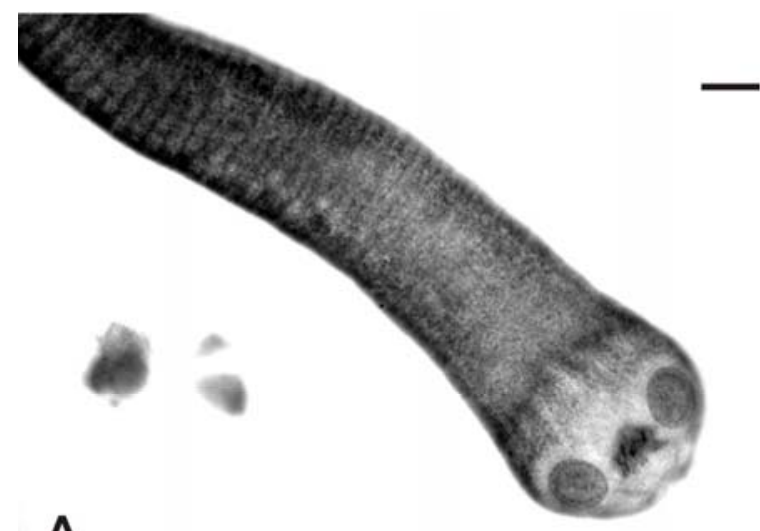

A

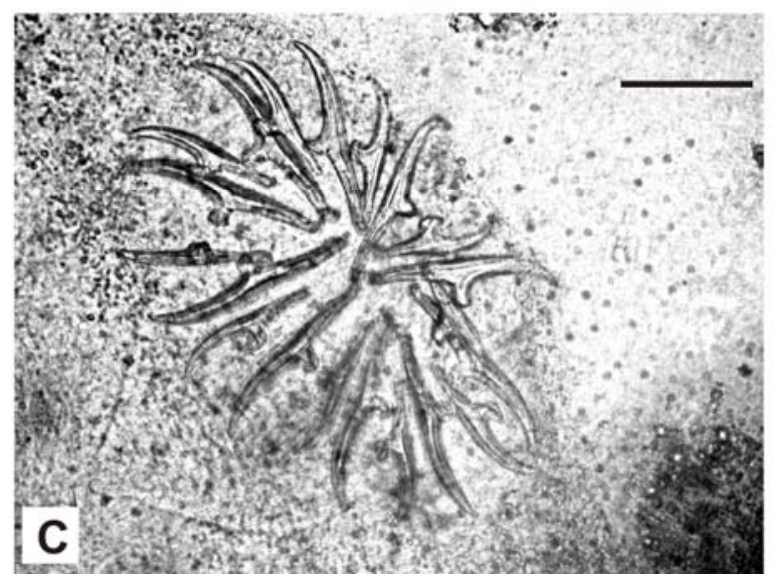

lengthwise, washed with physiological saline $(0.9 \% \mathrm{NaCl})$ and observed under the stereomicroscope for $P$. scolecina. The tapeworms found during such examinations were counted and then fixed in $70 \%$ ethanol with $5 \%$ glycerol. Measurements and photographs were taken under an Olympus microscope with image analysing software Multiscan v.4.2. In each season, 20 randomly chosen tapeworms from a cormorant were measured. The measurements were taken of such features as the length and width of the tapeworm body, the length of long and short hooks, the diameter of the scolex and suckers.

\section{Results}

The extensity and intensity of infestation in cormorants and the tapeworm dimensions are shown in Table 1. Except in autumn 2007, the extensity of infestation in cormorants with $P$. scolecina, was as high as $100 \%$. The infestation intensity varied and ranged from 3 to 8765 tapeworms per bird. All the tapeworms were found inside the small intestine. A particularly high intensity of infestation was found in the birds shot in August of 2006 and 2007. The average intensity of infestation in August 2006 was 4697, and in August 2007 - 2562 tapeworms per bird. Most of the tapeworms were young individuals, less than $2 \mathrm{~mm}$

Fig. 1. Paradilepis scolecina. A - young specimen; B- adult specimen's rostellum armed with hooks; C, D- large and small rostellar hooks. (Scale bar: A-B $=100 \mu \mathrm{m} ; \mathrm{C}-\mathrm{D}=50 \mu \mathrm{m})$ 
long (Fig. 1A). The intensity of infestation autumn was less than one tenth of the above value - in 2006 it was 403, and in 2007 - 167 tapeworms per bird. Most of them were adult tapeworms whose body was over $3 \mathrm{~mm}$ long (Fig. 1B). The lowest average intensity of infestation was found in the spring of 2006 - 61 tapeworms per bird. The width of scolex and strobila of the tapeworms under study depended on their length. No correlation between the length of hooks and diameter of suckers on the one hand and the tapeworm length on the other was found. The length of large and small hooks (Fig. 1 C, D) lay within the low limits of dimensions typical of the species (Ryzhikov et al., 1985).

\section{Discussion}

The results obtained in the study indicate that the intensity and extensity of infestation in cormorants from the colony situated on Lake Selment Wielki is very high and clearly indicates the presence of seasonal fluctuations. The highest intensity of infestation in both study periods was found in the cormorants shot in August. This is a period of intensive preying for birds (Wziątek et al., 2005) when they prepare for a journey to the winter habitats after the breeding period. Such a high intensity of infestation in cormorants indicates the widespread occurrence of tapeworm larvae in the fish that they consume. In the available literature there are no reports on the occurrence of larval stages of the tapeworm in fish from the reservoirs situated near the colony under study. The study into fish from Mazurian lakes (Mamry Północne, Święcajty, Stręgiel, Gołdapiwo), conducted for many years by Kozicka (1971) did not reveal a high extensity or intensity of infestation. In the years 1954 - 55, individual plerocercuses of the tapeworm $P$. scolecina were found by the author only in bleak (Alburnus alburnus) from Lake Gołdapiwo. In 1956, the author examined 16 bleak (Alburnus alburnus) from Lake Mamry and found $1-2$ tapeworm plerocercuses only in 4 of them; in 1957, 6 out of 29 examined fish were found to be infected by the tapeworm, with the intensity ranging from 1 to 19 larvae per fish. Much lower extensity and intensity were found by the author in roach (Rutilus ruti$l u s$ ) and crucian carp (Carassius carassius) from the reservoirs under study. The very low indicators of tapeworm infestation in the fish can be explained by a low size of the cormorant population in Poland. At the turn of the $19^{\text {th }}$ and $20^{\text {th }}$ centuries, the European population of cormorant included only $3500-4500$ couples, 150 of which lived in Poland (Przybysz, 1997). The size of the cormorant population was positively affected by covering the birds by legal protection in Poland from 1952, the growth of cyprinid and percid populations as well as by the cessation of using DDT-containing pesticides in agriculture. Over the past 20 years, the size of the European cormorant population has increased from several thousand in 1980 to about 200 - 250 thousand couples in 2000. The cormorant population in Poland in the years 1981 - 1992 is estimated to have increased by $14 \%$ annually. Currently in Poland there are about $20-22$ thousand couples of cormorants (Przybysz et al., 1988; de Nie, 1995; Carss, 2003).

Such a rapid increase of the cormorant population size in Poland must have affected the population of parasites for which the cormorant is the definitive host. The study of parasitefauna of bream (Abramis brama) from Lake Kortowskie, conducted in $1983-84$, did not reveal the presence of plerocercuses of $P$. scolecina (Kukliński, 1984). A study into the bream from the same lake, conducted in 1994 by Dzika (2002) showed that that the tapeworm larvae were present in $27.8 \%$ of the fish. According to the author, this may have been caused by frequent preying of cormorants from the constantly growing colony on Lake Wulpińskie. Dzika (2003) found considerable differences in the occurrence of $P$. scolecina larvae in the fish from the reservoirs situated at various distances from cormorant colonies. Larvae of this tapeworm has also been found in the fish from the Bay of Gdańsk and the Vistula Lagoon at the potential preying sites of cormorants from the colony in Kąty Rybackie (Rolbiecki et al., 1999; Rolbiecki, 2003). Rolbiecki (2003) examined 3 fish species from the order Perciformes and 13 species from the order Cypriniformes in the Vistula Lagoon and found the highest intensity of infection with $P$. scolecina in roach (5.7). The available literature does not contain reports on the occurrence of the tapeworm in fish from other water reservoirs in Poland. The high extensity and intensity of the tapeworm infection in cormorant, found in the study, may imply a high extensity and intensity of infection in fish. The study has revealed considerable seasonal fluctuations in the intensity of infection in cormorants. Both in 2006 and in 2007, the maximum intensity of infections in August was as high as 8 thousand tapeworms in a bird, whereas in spring it was 125 , and in autumn - a thousand tapeworms in a cormorant. Such a high intensity of infections in August may have resulted from intensive preying in the months preceding the shooting, which is indicated by a large percentage of tapeworms with a short strobila. Wziątek et al. (2005) found the cormorants from the colonies situated on lakes Wulpińskie, Mamry and Wigry to consume the largest amounts of fish in July and August. Similar seasonal fluctuations in the intensity of infections with the nematode Contracaecum rudolphii have been observed by Torres et al. (2000) in cormorants from several colonies in Chile. The authors did not find any seasonal differences in nematode infections in the fish from the area under study, but they did find considerable differences in the composition of cormorant diet, which - in the authors' opinion resulted in seasonal changes in the infection intensity in cormorants. The study conducted by Martyniak et al. (1997b, 2003) into the diet of cormorants from a colony in Karty Rybackie has revealed seasonal fluctuations in the diet. In March, the dominant fish species in the cormorants' diet were perch $(27.9 \%)$, roach $(24.2 \%)$, smelt $(20.2 \%)$ and ruffe $(14.7 \%)$. In the subsequent period from April to August, the diet was dominated by ruffe (85.9\%). However, according to many authors (Goc et al., 1997; Bzoma et al., 2003), the cormorant can modify its feeding 
behaviour in a very short time. Underwater preying takes a lot of energy (Carss, 1997); therefore cormorants frequently catch the fish swimming just under the water surface. Very frequently, this includes the fish whose behaviour has been changed by larval stages of birds' parasites (Barber et al., 2000). Experiments have shown that fish infestation by larvae of the tapeworm Schistocephalus solidus swim closer to the water surface than those uninfected (Lobue \& Bell, 1993).

This study also found a significant difference between the infestation intensity and the tapeworm length. In summer, when the intensity of infestation in cormorants is very high, the average tapeworm length was 2.25 and $2.34 \mathrm{~mm}$, while in autumn, when the intensity was much lower, the parasite length was 3.72 and $3.62 \mathrm{~mm}$. A decrease in the tapeworm length in birds with a high infection intensity has also been observed by Korpaczewska (1963) and Reece (1989). This may have been caused by overpopulation, which affects the parasite's phenotype (Niewiadomska et al., 2001). A negative correlation between the intensity of nematode C. rudolphii infestation and the nematode length and the amount of eggs produced by females has been determined by Dezfuli et al. (2002). Such correlations were not found in this study in the spring of 2006. Despite a low intensity of infestation, the length of tapeworms found in the birds was short. It is the time when the birds come from their winter habitats and the intensity of preying is lower than in July and August (Wziątek et al., 2005). Such a large difference between infestation intensity in spring, soon after the birds return from the winter habitats, and in summer and autumn, suggest that they become infected with the parasite in Poland. There have been no reports in the available literature on the occurrence of the tapeworm in the fish in the cormorant winter habitats. According to Mokwa et al. (2005), cormorants ringed in Poland have usually been found to the west or to the south of their breeding colony. The farthest displacements were to Tunisia, Egypt, Algeria and Spain.

The effect of cormorants on aquatic ecosystems may be considered in two aspects: the effect of birds on the fishing economy and the role that they play in a lacustrine ecosystem (Gmitrzuk, 2004). The cormorant is a typical ichthyophagous bird, which feeds on various fish species, with dominating small cyprinids and percids, which account for most of the biomass in highly trophic lakes (Prejs, 1978). Among the species eaten only sporadically by cormorants are pike, whitefish and vendace (Wziątek et al., 2005). Another important aspect of the cormorant's role in the environment is its sanitary effect on the fish population; removing the individuals infected with parasites (van Dobben, 1952; Mellin, 1990; Barber, 2003), which account for an increasing portion of the population as the eutrophication process progresses (Prejs, 1978; Dzika, 2003). On the other hand, the cormorant is a highly "attractive" definitive host for many parasites: due to its mobility between water reservoirs on different continents it can contribute to their widespread propagation (Barber, 2003). Many of the parasites whose larvae have been found in the bodies of consumed fish grow and reach the stage of sexual maturity in the cormorant's body. Eggs produced by females are excreted with a cormorant's faeces to water, where they reach subsequent stages of their development. According to Rolbiecki et al. (1999), a particular role in the propagation of aquatic parasites in the Bay of Gdańsk and the Vistula Lagoon is played by birds from the families Laridae, Phalocrocoracidae, Podicipedidae and Anatidae.

\section{References}

BARBER, I. (2003): The role of parasites in fish-bird interactions: a behavioural ecological perspective. In Cowx, I. G. (Eds): Interactions between Fish and Birds: Implications for Management, Fishing News Books, Blackwell Science Ltd., Oxford, UK

BARber, I., HoAre, D., Krause, J. (2000): The effects of parasites on fish behaviour: an evolutionary perspective and review. Rev. Fish Biol. Fisher., 10: 131 - 165

Bzoma, S. Goc, M., Brylski, T., Stempniewicz, L., ILISZKO, L. (2003): Seasonal changes and intra-colony differentiation in the exploitation of two feeding grounds by Great cormorant Phalacrocorax carbo sinensis breeding at Kąty Rybackie kolony. Vogelwelt, suppl., 124: 175 181

CARSS, D. N. (1997): Techniques for assessing cormorant diet and food intake: towards a consensus view. Ric. Biol. Selvaggina, suppl., 26: $197-230$

CARSS, D. N. (2003): Reducing the conflict between Cormorants and fisheries on a pan-European scale. Report to the European Commission (REDCAFE final report).

DE NIE, H. (1995): Changes in the inland fish populations in Europe in relation to the increase of the Cormorant Phalacrocorax carbo sinensis. Ardea, 83: 115 - 122

Dezfuli, B.S., VAlPoni, S., Beltrami, I., PaUlin, R. (2002): Intra-and interspecific density-dependent effects on growth in helminth parasites of the cormorant, Phalacrocorax carbo sinensis. Parasitology, 124: 537 - 544

DZIKA, E. (2002): The parasites of Bream Abramis brama (L) from Lake Kortowskie. Arch. Pol. Fish., 10: 85-96

DZIKA, E. (2003): Metazoan parasites of roach Rutilus rutilus (L.) in the lakes of Mazury District as a quality indicator of aquatic environment. Dissertations and monographs. UWM, Olsztyn (in Polish)

DziKA, E., RotKIEWICZ, T., HofFMANN, R.W. (2005): Histopatological examination of liver and spleen of roach Rutilus rutilus (L) originating from selected lakes of Warmia and Mazury Lakeland in Poland. Zool. Polon., 50: $33-47$

GMITRZUK, K. (2004): The Phalacrocorax carbo cormorant's influence on the aquatic and forest ecosystems of Węgierski National Park. Parki Narodowe i Rezerwaty przyrody 23: 129 - 146 (in Polish)

Goc, M., IliszKo, 1., CheŁKowskA, N. (1997): Daily foraging rhythm at a cormorant Phalacrocorax carbo colony during the breeding season. Ric. Biol. Selvaggina, suppl. 26: $445-451$ 
JARECKA, L. (1970): On the life cycles of Paradilepis scolecina (Rud., 1819) Hsü, 1935 and Neogryporhynchus cheilancristrotus (Wedl, 1855) Baer and Bona, 1958 - 1960 (Cestoda-Dilepididae). Bull. Acad. Pol. Sci., 15: 159 - 163

Karstad, L., SileO, L., OKech, G., Khalil, L.F. (1982): Pathology of Paradilepis scolecina (Cestoda: Dilepididae) in the white-necked cormorant (Phalacrocorax carbo). J. Wildl. Dis., 18: 507 - 509

KORPACZEWSKA, W. (1963): Tapeworms of aquatic birds in some Mazurian lakes. Acta Parasitol. Pol., 9: 81 - 93 KozICKA, J. (1971): Cestoda larvae of the family Dilepididae Fuhrman, 1907 parasitizing freshwater fish in Poland. Acta Parasitol. Pol., 19: 81 - 93

KUKLIŃSKI, K. (1984): Infestation and its impact on the health of bream Abramis brama (L) in Lake Kortowskie. MS Thesis, AR-T Olsztyn (in Polish)

Lobue, C. P., Bell, M. A. (1993): Phenotypic manipulation by the cestode parasite Schistocephalus solidus of its intermediate host, Gasterosteus aculeatus, the threespine stickleback. Am. Natur., 142: 725 - 735

Martyniak, A., Mellin, M., Stachowiak, P., Wittke, A. (1997a): Food composition of cormorants Phalacrocorax carbo sinensis in two colonies in north-east Poland. Ekol. Pol., 45: 245

Martyniak, A., Terlecki, J., Boroń, S., Hliwa, P., SZAMAŃSKA, U., GABRYŚ, B., ROMANIEWICZ, A. (1997b): Diet composition of cormorants Phalacrocorax carbo sinensis from pellets collected at Katy Rybackie colony, northern Poland. Ric. Biol. Selvaggina, suppl. 26: 505 - 510 Martyniak, A., WZiąTeK, B., SZYMańsKa, U., HLiWa, P., TERLECKI, J. (2003): Diet composition of Great Cormorants Phalacrocorax carbo sinensis at Katy Rybackie, NE Poland, as assessed by pellets and regurgitated prey. $\mathrm{Vo}^{-}$ gelwelt, suppl. 124: $217-225$

MELlin, M. (1990): The preliminary results of the cormorants dissection (Phalacrocorax carbo sinensis) shot in Mazury. Notatki Ornitol., 31: 53 - 59 (in Polish)

Mokwa, T., Bzoma, Sz., GromadzKI, M. (2005): Where from and where are the cormorants Phalacrocorax carbo observed in Poland migrating? Materials from Ornitology Conference. Olsztyn, Poland: 82 (in Polish).

Murai, E., Molnar, K., GubanYI, A. (1996-97): Occurrence of the plerocercus forms of the Paradilepis scolecina (Rudolphi, 1819) (Cestoda: Dilepididae) in Lake Balaton, Hungary. Parasit. Hung., 29 - 30: 33 - 38

Niewiadomska, K., Pojmańska, T., Machnicka, B., Czubaj, A. (2001): Outline of General Parasitology. PWN, Warszawa (in Polish)

PREJS, A. (1978): Lakes Eutrofisation and the ichtiofauna. Wiad. Ekol., 24: 201 - 208 (in Polish)
Prost, M., (1994): Fish diseases. PZWL, Lublin (in Polish) PrZyBysz, J. (1997): Cormorants. Wyd. Lubelskiego Klubu Przyrodników, Świebodzin (in Polish)

Przybysz, J., Engels, J., Mellin, M., Mrugasiewicz, A., PRZYBYSZ, A., PRZYBYSZ, K. (1988): A quantitative increase of cormorant (Phalacrocorax carbo sinensis Shaw et Nodder) populations in Poland. Przegl. Zool., 32: 71 - 81(in Polish)

REECE, R. L. (1989): Avian pathogens: their biology and methods of spread. In Cooper, I. E. (Eds): Disease and Threatened Birds. International Council for Bird Conservation Technical Report No. 10, pp $1-24$

RolBIECKI, L. (2003): Diversity of the parasite fauna of cyprinid (Cyprinidae) and percid (Percidae) fishes in the Vistula Lagoon, Poland. Wiad. Parazytol., 49: 125 - 164 RolbIECKI, L., ROKICKI, J., MOROZIŃSKA-GoGOL, J., ChIBANI, M. (1999): Larval stages of helminths in fish from the Vistula Lagoon and the Gulf of Gdańsk in relation to bird occurrence. Bull. Fish. Inst., 2: $51-60$

RYBICKA, K. (1958): Tapeworms of birds (excl. Anseriformes) in Drużno Lake. Acta Parasitol. Pol., 6: 143 - 178 RYZHIKOV, K. M., RYŠAVÝ, B., KhOKHLOVA, I. G., Tolkatcheva, L. M., Kornyushin, V. V. (1985): Helminths of Fish-Eating Birds of the Palaearctic Region II. Cestoda and Acanthocephales. Moscow/Praque

ScHOLZ, T. (1989): First record of the larvae of Paradilepis scolecina (Rudolphi, 1819) (Cyclophylidae: Dilipididae) in fishes from Czechoslovakia. Folia Parasitol., 36: $65-66$

Scholz, T., Bray, R.A., Kuchta, R., ŘEPOVÁ, R. (2004): Larvae of gryporhynchid cestodes (Cyclophyllidea) from fish: a review. Folia Parasitol., 51: 131 - 152

Szostakowska, B., Sulgostowska, T. (2004): Helmintofauna of the black cormorant (Phalacrocorax carbo sinensis) from North-Eastern Poland. Wiad. Parazytol., 50: 119

Torres, P., VAldiviesa, J., Schlatter, R., Montefusco, A., Revenga, J., Marin, F., LAmilla, J., RAmallo, G. (2000): Infection by Contracaecum rudolphii (Nematoda: Anisakidae) in the Neotropic cormorant Phalacrocorax brasilianus, and fishes from the estuary of the Valdivia river, Chile. Stud. Neotrop. Fauna \& Environm., 35:101-108

VAN DOBBEN, W. H. (1952): The food of cormorant in the Netherlands. Ardea, 40: $1-63$

Wziątek, B., Martyniak, A., Hliwa, P., Kozlowski, J., Krzywosz, T., OsewsKi, M., Sobocki, M., SzAmańSKA, U., GomuŁKa, P. (2005): Great Cormorant predation on coregonid fishes at sites in Poland. Advanc. Limnol., 60: $285-297$ 